\title{
THE YOUNGER GENERATION'S MAGAZINES IN THE EYES OF THE COMMUNIST IDEOLOGUES
}

\begin{abstract}
Aleš GABRIČ*
The contribution analyses the increasing criticism, voiced by the younger generation of Slovenian intellectuals from the first post-war years until the end of the 1950s. The critical attitude towards the pressing social issues started developing in the beginning of the 1950s, as Mladinska revija - the first post-war literary magazine, published between 1946 and 1951 - was still subject to thorough scrutiny by the authorities. In the period of its successor - the Beseda magazine between 1951 and 1957 - certain more radical debates or critiques of the existing situation were already published. This publication stopped coming out in 1957 . However, contrary to what the authorities had expected, a similar circle of the associates of this magazine's successor, the Revija 57 magazine (published in 1957 and 1958), was even more critical of the situation in the state. This contribution thus follows two parallel processes: on the one hand the increasingly critical attitude of the younger-generation intellectuals towards the authorities; and on the other hand the mounting pressure that the authorities exerted against magazines that published critical texts. At first the publications were merely the focus of political disapproval, followed by the abolishment of subsidies and thus consequently the cancellation of the magazines; while towards the end of the 1950s we can already come across a judicial process against an author of socially-critical articles. The leading politicians at the end of the period under consideration already saw the younger generation of intellectuals as the (cultural) opposition.
\end{abstract}

Keywords: late 1940s, 1950s, Yugoslavia, Slovenia, Youth Magazines, Mladinska revija, Revija 57, Beseda

* Aleš Gabrič, Ph. D., Institute of Contemporary History, Ljubljana, Slovenia 


\section{Introduction}

The communist takeover of power in 1945 influenced cultural creativity as well, as the ideologues belonging to the ruling Party also appropriated the right to make decisions with regard to the cultural scene. The establishment of only a single expert society was allowed for each individual field of the arts or sciences, while the traditional association in smaller groups according to the ideological or stylistic similarities was prevented by the new authorities. The operations of cultural institutions and societies were supervised secretly by the Agitation and Propaganda Commission of the Central Committee of the Communist Party of Slovenia, which soon acquired the short name "Agitprop".

Similar to the arrangement in the field of associations, a single magazine for each individual field of expertise was supposed to exist as well. Novi svet started to be published as the central literary magazine, in which all the members of the Liberation Front (with various world views) were supposed to publish their contributions. The uniformity was also supposed to be reflected in the younger generation's literary magazine, of which only a single one was supposed to exist, naturally. The Party ideologues envisioned this magazine especially as a means of steering the young cultural workers towards the "proper" path. In this regard the youth were supposed to be led by the experienced writers who exhibited the "progressive" world view, and who had already been distinguished social realists before the war and had assumed the socialist realism tendencies after the war.

The enforcement of the one and only ideology resulted in the resistance of certain intellectuals already during the first year after the war. The diverse and lively pre-war publication scene was replaced by the greyness with no room for any vigorous debates of cultural workers with different opinions. Juš Kozak, the editor of the Novi svet magazine, described this situation after the first year of publishing without any reservations: "While we did not have any problems with the names publishing their contributions in the magazines in the recent past, today we must acknowledge our deficiency. Today we are stagnant - and this is a fact that we should acknowledge openly." In his deliberations, Kozak also looked towards those intellectuals who had, throughout history, been the first to reflect changes, the likes of which Yugoslavia had experienced between 1941 and 1945. Was it thus the younger generation of intellectuals that offered something new - something that could make an impact on the literary magazines? "The youth? Not even the youth," Kozak wrote disappointedly. ${ }^{1}$

Juš Kozak, “Nekaj zapiskov ob zaključku leta”, Novi svet, 1 (1946), no. 10: 819-820. 


\section{The Mladinska revija magazine}

The Mladinska revija magazine was founded in 1946 as the central and sole - of course - publication of the young generation. It was envisioned as a magazine tasked with steering young artists in the direction dictated by the cultural-political orientation of the ruling Communist Party. Already its editorial indicated that the Mladinska revija magazine was not supposed to contain a diverse range of various artistic orientations, but rather that it was supposed to follow the ideas of the political watershed that had resulted in the rise of the contemporaneous authorities. If youth magazines before the war tended to be belligerent, struggling for their rights and truth, this was supposedly no longer necessary: "Our 'Mladinska revija' will no longer be such a revolutionary call to arms. It will no longer seek new models and new truths around the world, for the truth is here among us, rooted deep in our hearts. This is the truth of the liberation struggle, the truth of the Slovenian people, and the truth of the poet Kajuh. With this truth in our hearts we will keep building and creating, constructing a new brand of youth, our people, and our nation."

The magazine stated clearly that the youth were not supposed to seek out new things, but rather toe the prescribed line. It was supposed to follow the idea of the Partisants, i.e. the "truth of Kajuh", the popular young poet who fell as a Partisan in 1944. Meanwhile, the "new brand of youth" contained a touch of the times when novelty implied (merely) what the ideologues of the new period presented as novel and progressive. This was especially the time of the restoration of the demolished homeland, accelerated industrialisation, and formation of the cult of manual labour. The youth would supposedly be forged into loyal members of the new society, especially at the youth work actions where they were supposed to contribute to the construction of a better future by means of voluntary work. Such literature, focusing on celebrating the successes of the new regime, soon started to be referred to pejoratively with the terms "kramparstvo" and "lopatarstvo" (i.e., writing with mattocks and shovels). This sort of art had little room for love and eroticism, intimacy, or intimate impressions of the changing world. The first volumes of the magazine thus contained many contributions that focused on the wartime years and described the battles, marches, and life in the concentration camps, accompanied by graphic materials on the same theme. The contributions would mostly describe the events - suffering on the one hand and heroism on the other, both of these very one-sidedly. The authors would only rarely immerse themselves in the mental world of the protagonists. Their articles would only skim the surface and frequently lean towards the declared socialist realism by depicting the reality in black and white. The initial phase of the Mladinska revija magazine

"Uredništvo", Mladinska revija 1 (1946), no. 1: 1. 
was also marked by the absence of intimate lyricism or simple short prose on the everyday problems of everyman in the context of their immediate living environment. Numerous authors published short contributions in the magazine, but many of them were unable to navigate their way through the literary world: later, when the artistic endeavours started looking towards broader horizons, we can no longer find them among the literary magazine associates.

The editorial policies thus followed the tendency that at the beginning of their path, the youth should listen to their older colleagues. The mentorship spirit of the magazine was also apparent from the publication of the works by the well-established Slovenian social realist writers as well as translations of the works by renowned authors from the Soviet Union. These works were supposedly bright examples that the younger generation of artists should follow. As during the first years the editorship of the Mladinska revija magazine followed the cultural-political demands of the authorities, its work was not notably criticised. The activities of the magazine were supervised by the People's Youth of Slovenia. Its ideological centre, the Agitprop of the People's Youth of Slovenia, praised the first issues of the magazine, as they were supposedly "on a very high level - so that not every youth dares to publish their texts in it". The editorship supposedly took care "especially of the broad Marxist and Leninist education". ${ }^{4}$ However, the members of the editorship warned the propagandists that the majority of the magazine's associates were nevertheless interested in fine literature, and therefore the part of the editorship in charge of the Marxist education had to be strengthened. Associates should be sought especially in the ranks of the blue-collar and peasant youth, "in order to gradually ensure the budding of truly healthy people's artists". The editorship also drew up "a detailed five-year programme that can be implemented in its totality, probably with but a few minor changes." ${ }^{5}$

Like many times in history, the wishes expressed by the political circles were one thing, while the reality and the wishes of the younger artists were completely different. In the editorial, published in the first issue of the second volume of the magazine, the managing editor France Kosmač admitted, already in the first sentence, "that we cannot be satisfied with it". ${ }^{6}$ In his rather critical analysis of the first volume of the magazine, Kosmač believed that the contributions were superficial and lacking any profound insight, and saw the reason especially in the fact that those authors who would have been best suited to publish their works in this magazine had not responded to the call for par-

\footnotetext{
3 Arhiv Republike Slovenije (hereinafter: AS) AS 1799, t.e. 12, Zapisnik seje sekretariata glavnega odbora LMS, June 12, 1946.

4 AS 1799, t.e. 12, Predlogi konkretnih nalog marksistično-leninistične vzgoje organizacij LMJ, 26. 7. 1946; priloga k: Zapisnik širšega sestanka sekretariata GO LMS, July 27, 1946.

$5 \quad$ AS 1799, t.e. 12, Zapisnik širšega sestanka sekretariata GO LMS, July 27, 1946.

6 France Kosmač, “Naš obračun”, Mladinska revija, 2 (1947), no. 1, p. 1.
} 
ticipation. These authors were especially students at the University and at the Academies of Arts. The managing editor emphasised that they had merely voiced their criticism of the magazine, but refrained from sending any contributions for potential publication. Kosmač especially hoped for the cooperation of the students at the central humanities faculties, "especially the Slavicists from the Faculty of Arts. Not one of the approximately 160 Slavicists who studied at the University contributed anything in 1946."

The complaints about numerous artists declining to participate in the central magazines were not characteristic only of the Mladinska revija magazine, as similar assessments were also made with regard to Novi svet, the central literary magazine. The Party ideologues were aware that some of the intellectuals who had taken part in the Partisan struggle and considered themselves a part of its tradition refused to follow the promoted cultural-political orientation. They also expressed their refusal of the dogmatically-Marxist outlooks on the arts by declining to cooperate with the magazines, which, according to the opinion of the cultural workers, focused on promoting an idea rather than allowing enough room for personal expression.

In the subsequent years, the situation did not improve. The Mladinska revija magazine remained a medium that was supposed to advise the youth with regard to the types of culture that were appropriate for the political moment at hand, while it was not supposed to publish any critical responses to the current socio-political circumstances. The mentorship character of the magazine was emphasised with the publication of numerous cultural-political articles and advice to the youth with regard to what they should be creating, as well as with the critiques of ideologically inappropriate works. The largest quantity of this type of contributions in one place was published in the double issue of the volume 1948-49, which contained materials from the founding general meeting of the Association of Young Cultural Workers of Slovenia. This Association was poised to become the (only) framework for the activities of all young cultural workers, and its members were supposed to adhere to the socialist realism dogma. ${ }^{8}$

The introductory speech at the founding congress of the Association was given by the writer Ivan Bratko, an important communist cultural ideologue. ${ }^{9}$ The speech was heavily laden with political terminology, and in it Bratko emphasised that the youth allegedly refused culture, as it was seen from the Marxist point of view, more rarely than the older generation, which had already been

\footnotetext{
Ibidem, p. 4.

8 More about society: Aleš Gabrič, “Zveza mladih kulturnih delavcev Slovenije”, Nova revija, 19 (1991), no. 113-114, pp. 1235-1245.

9 Ivan Bratko, “O kulturi in umetnosti naše mlade generacije”, Mladinska revija, 4 (1948-49), no. 3-4, pp. 65-73.
} 
shaped in terms of ideology. The young generation was not supposed to look for any new directions, as "they are in no way different from the rest, as far as any new ideological-political or literary orientations are concerned". This generation's peculiarity was allegedly simply that "they primarily focus on learning and studying, as they are preparing for their future work". The youth thus only had to listen, merely follow the words and ideas (as dictated from above), and they should by no means be "a sort of a young avant-garde". ${ }^{10}$ Bratko underlined that the path that had already been paved for the youth was the path of socialist realism. ${ }^{11} \mathrm{He}$ also listed a few examples of what was, according to him, inappropriate literature, written by none other than two young authors who had already been detained in the communist prisons at the time -as if the speaker wanted to show the young cultural workers where they could end up, should they make wrong decisions with regard to their path.

The Association of Young Cultural Workers of Slovenia also became the official publisher of the Mladinska revija magazine, and its editorship was tasked with adapting the selection of the contributions to the cultural-political demands of the authorities. Already the order in which the tasks of the editorship were listed indicated what was important: "In the new volume, the 'Mladinska revija' magazine should focus especially on the ideological and artistic quality of the published contributions, as well as on the task of educating a broad circle of associates without deviating from our general political, economic, and cultural life." 12

In 1948 and 1949, the cultural policies of the Communist Party of Yugoslavia started to change rapidly due to the foreign-political dispute between the Soviet Union and Yugoslavia. Initially the Yugoslav leaders hoped to prove to the Soviets that they were true Marxists and Leninists, and they emphasised their loyalty to the ideology particularly loudly. However, in the first half of 1949 the most rigid dogmas, adopted during the copying of the Soviet cultural-political model, started to be abandoned. ${ }^{13}$ In this period - in the summer of 1949 - Ivan Minatti and Mitja Mejak were appointed as the editors of the Mladinska revija magazine. ${ }^{14}$ The choice was far from random. Both had asserted themselves as perspective young authors, while they were also ideologically acceptable, as they took part in the approved public life forums. For example, Ivan Minatti also discussed the Mladinska revija magazine and the Association of Young Cultural Workers of Slovenia at the congress of the People's Youth of Slovenia in April 1949. He underlined that the magazine had su-

\footnotetext{
$10 \quad$ Ibidem, p. 67.

11 Ibidem, p. 71.

12 AS 1799, t.e. 6, a.e. 1, Poročilo o delu LMS v letu 1948, p. 40.

13 Aleš Gabrič, "Preokret kulturno-političke linije KPJ posle Rezolucije Informbiroa", Istorija 20. veka, 18 (2000), no. 1, pp. 101-108.
} 
cceeded in attracting several talented young cultural workers, while it was still most popular among the youngest generation: "It has elicited most responses and found the largest number of participants among the secondary school pupils." Minatti underlined that unfortunately the magazine failed to ensure the cooperation of those who could have made the greatest impact on the formation of the cultural and ideological outlook of the future generations: "I have to bring the attention to the peculiar attitude of the Ljubljana University Slavicists, who are actively involved in the field of literature, towards the efforts of the young authors. Their minimal participation and arrogant attitude shed a strange light on our future educators, who will eventually be in charge precisely of the youth cultural education." ${ }^{15}$

Perhaps the selection of the new editors was influenced by the fact that at the time Minatti himself was a Slavic studies student, and those in charge probably counted on him imparting the spirit of the new times on the ranks of those who seemed to be either boycotting or ignoring the activities of the youth cultural working groups and the Mladinska revija magazine. Ultimately the new editors did manage to expand the circle of associates, but the results by no means fulfilled the expectations of the Party cultural ideologues. Already in the first volume published by the new editorship, in the year 1948/49, debates appeared on the pages of the magazine, criticising also what had previously been heavily promoted literature that celebrated the new times without any reservations. The changes in the literary work of the young generation were also noted by the ideological centre of the authorities - the Agitprop of the Central Committee of the Communist Party of Slovenia, which stated the following towards the end of 1949: "Some of the youngest literary authors have recently exhibited increasingly strong tendencies to underestimate ideology. This is related to the improperly-understood critique of 'ideology' in the Soviet literature. However, we believe this to be a very transitory phenomenon, which we will surely overcome as we discuss these issues."16

This prediction of the Party ideologues turned out to be wrong, just like the majority of their predictions in these pivotal years. As it was, next year, in 1950, the Mladinska revija magazine changed its direction completely and became a publication that the Party ideologues would end up arguing with increasingly often - just like with its successors. The conflicts did not (only) take place behind the scenes, but rather simply publicly. In April 1950, at the second literary consultation of the Association of Young Cultural Workers of Slovenia, the younger generation of intellectuals publicly questioned the previously promoted cultural-political guidelines. This consultation also meant the end of

14 AS 1799, t.e. 57, Poročilo o delu redakcije Mladinske revije v letu 1948/49.

15 AS 1799, t.e. 8, IV. kongres LMS, razprava Ivana Minnatija.

16 AS 1589 , III, t.e. 31 , a.e. 835 , Poročilo o vsebini in metodah dela v literaturi, likovni umetnosti, glasbi, igralski umetnosti in filmu v letu 1949. 
this association, based on the socialist realist doctrine. The younger generation of artists attacked the principles of socialist realism as well as discussed their own previous work quite self-critically. In their opinion, art had to present a variety of outlooks: rather than insisting on a single truth, it should also examine other viewpoints. Thus France Balantič, a poet and Kajuh's peer who, unlike Kajuh, fell during the war as a member of the Home Guard - i.e. a member of the military formation that collaborated with the German occupiers - was evaluated positively by the younger generation. This incensed the older-generation writer Miško Kranjec: "Our young poets certainly have nothing to learn from Balantič. At the same time, people are talking about and sort of ridiculing the poetry of 'shovels and mattocks' nowadays, which is what certain young poets supposedly engaged in during the youth work actions. (...)To mock the poetry of the 'mattock' and at the same time praise Balantič, who supposedly had a fire burning inside him, is definitely to ignore reality, implying that politics - as well as 'mattocks', if you will - vulgarise poetry." ${ }^{17}$

Others who argued in favour of the thesis that art should adapt to the political demands - among them, for example, the Slovenian Minister of Science and Culture Jože Potrč and a visible member of the Agitprop of the Central Committee of the Communist Party of Slovenia Ivan Bratko - expressed their disagreement with numerous opinions of the younger generation of intellectuals. The consultation was a completely obvious sign that as of that moment the younger generation would seek their own path and renounce the mentorship and advice of the older or Party ideologues. The following volume of the Mladinska revija magazine, 1950-51, was a prologue to the conflicts that caused the leading communists to increasingly often see the nascent intellectual generation that had formed after the war as a political problem.

In February 1951, Minister Jože Potrč addressed this issue as well at the most important political forum - the plenum of the Central Committee of the Communist Party of Slovenia. This was the first time that he included the younger literary generation among other pressing political problems and emphasised "that our Mladinska revija has been known to publish what I won't refer to as decadent, exactly, but certainly somewhat peculiar things". ${ }^{18}$ The head of the Slovenian Agitprop Boris Ziherl agreed with this critical outlook and listed a few authors who were inappropriate, in his opinion. ${ }^{19}$ Furthermore, at this political forum the assessment that such attitude should be prevented was voiced for the first time. Boris Kidrič proposed without embellishing: "I'd simply take away all their subsidies." Ziherl reminded the critics that such demands could not be literally included in the resolution, but that the fact that the poli-

\footnotetext{
“Glavne misli iz diskusije po referatih", Mladinska revija, 5 (1949-50), no. 9-10, p. 444.

18 AS 1589, IK, t.e. 1, Zapisnik V. plenarnega zasedanja CK ZKS, February 16-17, 1951, p. 65.

19 Ibidem, p. 81.
} 
ticians did not agree with the circle of the Mladinska revija magazine should be brought to the magazine's attention. The leading communists took this into account and formulated their opinions in a somewhat more relaxed manner, yet nevertheless clearly enough to intimidate those who thought differently into considering the lines that they should not cross with their work: "In this regard we should pay special attention to our youth literature and resolutely reject any indications of moral decay and lack of belief in people, in so far as such tendencies attempt to invade literature." ${ }^{20}$

In February 1951 the monopoly political party thus warned the younger intellectual generation that in case of "disobedience" the authorities were prepared to use their power in order to prevent any "inappropriate" cultural creativity. However, the warning was not enough, as Mladinska revija gradually profiled itself as a "student" magazine, increasingly critical of the situation at the time. In the middle of 1951 rumours already started spreading about the termination of the magazine. Towards the end of this year that in fact happened, but the magazine was not replaced by vacuum. Instead it was immediately replaced by another publication, with the same editors and a similar circle of associates. The end of the Mladinska revija magazine could be seen as an autonomous decision of its editorship rather than as a response to the threats of the political leadership: the editors wanted to get rid of the name that alluded to the activism of the post-war years and implied that the young authors should learn from their elders obediently rather than head out on their own.

\section{The Beseda magazine}

Ivan Minatti became the editor of the Beseda magazine, which replaced Mladinska revija. Mitja Mejak remained in the editorial board as well, and in the subsequent years the circle of the magazine's associates even expanded. In the editorial, published in the first issue, the editorship explained why the magazine was renamed: "The new magazine Beseda was born from the wishes of young authors, dedicated, due to their inner passions, to the growth of the Slovenian culture and focused on their creative work, as the pages of the former Mladinska revija became too restrictive for them and its title too narrow. The importance of Mladinska revija should nevertheless not be underestimated. The new magazine grew from the best that Mladinska revija had to offer: the work, especially in the last volumes, that distanced itself from the impulsive cultural activism and started asking clear and resolute questions, as well as provided honest answers that have already asserted themselves in the cultural life." The editorship announced that it would - in the more relaxed atmosphere that now prevailed in the society - encourage debates, focus on essays and cri-

$20 \quad$ Ibidem, p. 92. 
tiques, and that everything that's worth laughing at would be poked and prodded with witty articles. The editors dedicated the conclusion of their editorial to those who thought differently - between the lines it was obvious that this included the ideologues of the new times, whom the editors reminded not to react to different opinions from the position of power and to refrain from implementing any unpopular measures: "The magazine or even the whole generation should not be punished because of their opinions! Youthful opinions are - even though they might turn out to be wrong - nevertheless seen as the driving force of progress!"21

The editorship followed the announced programme scheme, and Beseda brought a whiff of fresh air to the publishing scene. Critical and polemical essays introduced lively discussions into the cultural space, which had been non-existent for well over a decade. Janko Kos and Taras Kermauner were at the forefront with their fresh outlooks: on the pages of the Beseda magazine they led the discussions with the official cultural-political principles as well as the leading Party cultural ideologues. By publishing the critiques of the mainstream theatre programme and fine arts exhibition activities or, for example, by defending jazz music, which was the target of criticism of the communist ideologues, the magazine established a dialogue on the cultural scene. The first assessments of the Beseda magazine, published in the newspapers, were favourable, as the new magazine in fact enriched the cultural scene.

Not everyone shared this opinion, of course, which is especially true of the leaders of the Central Committee and the Agitprop of the Communist Party of Slovenia. Beseda became the subject of discussions at the sessions of the leading Slovenian political forums. At the session of the Political Bureau of the Communist Party of Slovenia, the contemporaneous tendencies at the cultural scene were pointed out as inappropriate, and the Beseda magazine was listed as one of the most pressing problems. In his introductory speech about these issues, Boris Kraigher, one of the leading Slovenian communists, called for a greater political engagement on the cultural scene and inquired "who in the Agitprop is responsible for the fact that Kocbek is printing books and that 'Beseda' writes what it does." 22 Thus he obviously hinted at Edvard Kocbek's book Strah in pogum (Fear and Courage), which depicted the dilemmas of the Partisans in an existential manner - very differently from the dominant black-and-white descriptions of the events in the Slovenian territory during the last war. Kraigher reproached the young intellectuals who cooperated with the Beseda magazine with following "Sartrism", which was, in the vocabulary of the communist ideologists, synonymous with enthusiasm about the French existentialism.

\footnotetext{
21 Beseda, I (1951-52), no.: 1-2.

22 Zapisniki politbiroja CK KPS/ZKS 1945-1954 (Ljubljana: Arhivsko društvo Slovenije, 2000), p. 283.
} 
The developments on the cultural scene were described in more detail by Boris Ziherl, head of the Agitprop of the Communist Party of Slovenia. He believed that the influence of the Western ideology was prominent in the works of certain Christian socialists (including Edvard Kocbek) and the young generation. He stated that already in the time of the Mladinska revija magazine the Agitprop approached the editors "Minatti and Mejak, demanding that the Mladinska revija magazine refrain from publishing texts that had been rejected elsewhere", but it was turned down. "They considered this to be worthy of Zhdanov," Ziherl added. Thus Ziherl actually admitted that the Agitprop successfully controlled what was published in other magazines, but that the $\mathrm{Be}$ seda magazine would reject this sort of "advice", oppose the political interference with the work of the editors, and deemed such endeavours as attempts at censorship. Ziherl went on to add that the work of the magazine would nevertheless have to be interfered with: "The three existing volumes of the 'Bese$d a$ ' magazine are at the very brink of what we had condemned at the time. (...) We should consider appointing a new editorship." The members of the leading Slovenian political authorities supported Ziherl, which resulted in retaliation against those in the cultural scene that disagreed. ${ }^{23}$

In the following weeks, pursuant to the decisions reached at the session of the Political Bureau of the Communist Party of Slovenia, Boris Ziherl made public appearances and encouraged the campaign against Edvard Kocbek and the Beseda magazine. At the conference with editors-in-chief and editors of the cultural sections of the central media on 3 January 1952, Ziherl listed several groups of the opponents of the Party cultural policy, who had been known to publicly promote the opening of Yugoslavia towards the West. "We have strayed from the Party line," he described the situation in the sphere of culture. He also mentioned the Beseda magazine as one of those who opposed the attempts of the Communist Party to dictate the developments on the cultural scene, as "the general tendencies of this magazine are anything but positive". Ziherl described the events in the field of magazine publishing with what was a completely political terminology, and described those who thought differently as advocates of different political principles: "Our cultural columns in the daily newspapers are in the hands of anti-Party elements. The direction of culture is dictated by precisely these elements. However, wherever culture is in the hands of the Party members, they tolerate liberalism. (...)There is no ideological struggle whatsoever going on for the elementary Marxist principles in literature and arts." Ziherl also mentioned that those with different opinions should not be forbidden to write, "as their articles will indeed be published; but first we have to make sure that the authors remove everything that does not belong in their texts." ${ }^{24}$ The leading Slovenian Party cultural ideologue thus ar-

\footnotetext{
$23 \quad$ Ibidem, p. 285.

24 AS 1589, III, t.e. 30, a.e. 783, Zapisnik konference z glavnimi uredniki in uredniki kulturnih rubrik centralnih listov in radia, January 3, 1952.
} 
gued for the interference with the autonomous work of editorships, while he used political jargon to describe his opponents as advocates of liberal values.

On the following day, on 4 January, Ziherl criticised the Beseda magazine at the meeting of the members of the Slovenian Writers' Association as well; while on 5 January he once again presented his initiative to replace the editors at the session of the Agitprop of the Central Committee of the Communist Party of Slovenia. ${ }^{25}$ In January 1952 the main newspapers published severe criticism of the magazine of the younger generation of intellectuals. However, uncharacteristically for the rest of the socialist bloc, the Yugoslav media at this time also published the arguments of the opposing side, in defence of Beseda. Ziherl intervened in the controversy directly as well, describing the magazine in question with a very political vocabulary on the pages of Ljudska pravica, a gazette of the Communist Party of Slovenia. He believed that Beseda was publishing "the most openly reactionary verses, essays, commentaries and epigrams" and added the following: "There are no traces of the struggle for the assertion of Marxist thought or the true pursuit of quality in the 'Beseda' magazine."26

Ziherl underlined his standpoints with a very concrete move. In 1952, Beseda was supposed to publish a translation of the article in which Jean Paul Sartre called upon Europe to establish itself as the third force between the West dominated by the United States and the East dominated by the Soviet Union. "Sartre himself - and his idea all the more so - represented a political offence, followed by Ziherl's intervention, and therefore the text that had already been typeset could not be printed," a member of the editorship Janko Kos remembered. He also stated that the article had been translated at his own initiative. However, in accordance with the established principles it was the editor Ivan Minatti who had to defend himself: he "was summoned by Ziherl and reprimanded appropriately". ${ }^{27}$

During the meeting not as visible to the public and to the editorship of $B e$ seda - at the Central Committee of the Communist Party of Slovenia session of 11 February 1952 - Ziherl presented various scenarios that the authorities would implement in the following years in order to subjugate the magazines of the disobedient intellectuals. He mentioned that the magazine was subsidised, but that "this is a group of people, completely removed from the political life" - a group that rejected the cultural-political and ideological guidelines of the ruling Party. He also mentioned the following possible measures that could be taken against this sort of publications: "Either we let the magazine fail

\footnotetext{
25 Aleš Gabrič, Slovenska agitpropovska kulturna politika 1945-1952. (Ljubljana: Mladika, 1991), pp. 630-631.

26 Boris Ziherl, “Še enkrat okrog 'Besede"“, Ljudska pravica, 13 (26. 1. 1952), no. 4: 10.

27 Janko Kos, Ideologi in oporečniki : spominjanja (Ljubljana: Znanstvena založba Filozofske fakultete, Beletrina, 2015), p. 46.
} 
by not subsidising it any longer (...).Or we could (...) replace it with a publication, which would in fact be a reflection of the literary creativity of students at the higher schools and universities, and which the Party would control completely." 28

The first proposal was soon discussed at the competent forum. In May 1952 , after it had covered the expenses incurred by the first volume of the $B e$ seda magazine, the commission for the subsidising of press at the Education and Culture Council of Slovenia wrote, with regard to the co-financing of the second volume: "The subsidising of the new volume depends on the evaluation by the political forums." 29 This evaluation was negative, however, which was also evident from the fact that the Education and Culture Council of Slovenia initially informed the editorship of Beseda that the magazine would not receive a subsidy for the year 1953. Then this decision was reconsidered and the magazine at least received somewhat more than a half of the promised amount. ${ }^{30}$ However, already in the second issue of 1953, the editorship of Beseda informed the readers that it had received a new notice from the competent state authorities, approving the whole subsidy. ${ }^{31}$

The first crisis of this magazine was over. We should not overlook the fact that the escalation of the dispute between the magazine of the younger generation of intellectuals and the orthodox ideologues took place precisely in the time when Yugoslavia was most evidently opening itself for the Western influences and when it had already started abandoning the cultural-political orientation of the previous years. The most obvious sign of this change, announcing the return of critique and controversy to the public scene, was the paper by Miroslav Krleža at the congress of the Writers' Association of Yugoslava in October 1952 in Ljubljana. ${ }^{32}$ This relaxation of the ideological restrictions from the previous period probably contributed to the fact that the public criticism of the Beseda magazine did not achieve the desired political effect. The critiques published in the mainstream media provoked responses from the opposing side and gave rise to lively debates. That Yugoslavia/Slovenia was nevertheless separate from the rest of the Eastern European communist world was also apparent from the fact that the standpoints of the main Slovenian

\footnotetext{
28 AS 1589, III, t.e. 40, a.e. 1282, Zapisnik seje o polit. problematiki ljubljanske univerze, February 11,1952 , p. 3 .

32 Stanko Lasić, Krležologija ili povijest kritičke misli o Miroslavu Krleži - knjiga četvrta. Stvaranje kulta: 1945-1963. (Zagreb: Globus, 1993), pp. 80-87; Ratko Peković, Ni rat ni mir : panorama književnih polemika 1945-1965. (Belgrade: Filip Višnjić, 1986), pp. 144-153; Ljubodrag Dimić, Agitprop kultura : agitpropovska faza kulturne politike u Srbiji : 1945-1952. (Belgrade: Rad, 1988); pp. 256-257; Aleš Gabrič, Slovenska agitpropovska kulturna politika, pp. 648-649.
} 
Party cultural ideologue Boris Ziherl also elicited a firm public response in the newspapers due to his criticism of Beseda. He and Janko Kos, one of the most renowned essayists from the circle of the Beseda magazine, engaged in a heated discussion, confronting the outlooks of an orthodox Marxist and a younger literary theorist. ${ }^{33}$ That the latter had the possibility to criticise an important Party ideologue in the central cultural press at all was a clear sign that a political change was underway in Yugoslavia: even just a few years earlier this would not have been possible, and either the magazine or the author would have been held responsible for such an action. Furthermore, Boris Ziherl was no longer able to speak as the head of the Agitprop. As it was, this central ideological and censorship centre of the communists was abolished after the congress of the Communist Party of Yugoslavia (and its renaming as the League of Communists of Yugoslavia), which took place in November 1952 in Zagreb. Thus the whole period of the so-called Agitprop cultural policy was brought to an end. ${ }^{34}$

In the middle of 1953, the editorship was taken over by Janko Kos and Ciril Zlobec, and the magazine started publishing even more controversial articles that deviated from the cultural-political convictions of the leading communists. During one of the debates, Ziherl stated that the ideological world of the associates of the Beseda magazine was quite different from the standpoints of the leading communists, and characterised Janko Kos in the following manner: "However, his views of historical materialism are somewhat particular and in my opinion different from what Marxists perceive as historical materialism." 35 On the other hand, Janko Kos wrote about his opponent that "it has already become too obvious that Ziherl's ideological authority has been in decline after 1952". ${ }^{36}$

The magazine's second crisis began in the middle of 1955 . The new publishing legislation set out that every publisher should have a publishing council, consisting of members appointed by the collective as well as members appointed by the founder. Since the authorities could influence the appointment of the second group, it would now be possible for them to influence the editorial policy of publishing companies and magazine editorships. When this act was adopted, Beseda was the only literary magazine without a founder. The Besede consortium was the formal publisher, while all the administrative tasks were carried out by the magazine's associates. Despite their good intentions and effort, the magazine was not published regularly. ${ }^{37}$ Due to delayed payments, towards the end of 1956 Blasnik's printing house informed the magazine that their collaborati-

\footnotetext{
33 Aleš Gabrič, “Od Mladinske revije do Perspektiv”, Borec, 46 (1994), no. 535/537: 1073-1075.

34 Gabrič, Slovenska agitpropovska kulturna politika, pp. 650-651; Dimić, Agitprop kultura : agitpropovska faza kulturne politike u Srbiji : 1945-1952., pp. 273-274.

35 Boris Ziherl, “Še enkrat o naši kritiki”, Naša sodobnost, 2 (1954), no. 4: 365.

36 Kos, Ideologi in oporečniki, p. 50.

37 AS 249, t.e. 100, doc. 135-55; Janko Kos, "Nekrolog za Besedo", Perspektive, 2 (1961/62), no. 11: $42-45$.
} 
on had come to an end. ${ }^{38}$ The authorities found a reason to once again exert pressure against the magazine in the publication of a part of the novel Zlati poročnik (The Golden Lieutenant) by the emerging writer Lojze Kovačič. The first part was published in the 1957 issue 1-2 of Besede, while the next part was published in issue 3. In his novel, Kovačič described the life of a soldier in the Yugoslav People's Army. He did not describe the Army as a forge of brotherhood and unity like the official propaganda did, but rather as a forced association of people from various cultural backgrounds, where insults and chauvinistic slurs were nothing unusual. Because of the publication of The Golden Lieutenant, in the beginning of April 1957 the court confiscated the third issue of Besede, of which only twenty copies were printed due to the problems that arose. ${ }^{39}$

When the Republican Secretary of Culture Vlado Vodopivec publicly discussed the affair a few days later, he mentioned that the Beseda magazine "operated in legally vague circumstances, which were not in accordance with the Publishing Act”. Thus the magazine's subsidy was revoked and transferred to the Prešernova družba company, which would supposedly start publishing a new magazine in accordance with the law. ${ }^{40}$ Vodopivec thus only underlined the legal aspects: that the editorship had been unable to adapt to the provisions of the new legislation. He did not, however, mention any ideological issues that the magazine was reproached with by the politicians. In May 1957, these reproaches were included in the publicly inaccessible document: the report of the Ideological Commission of the Central Committee of the League of Communists of Slovenia. The report mentioned that Beseda had been confiscated because "in the introduction it published an excerpt from the novel written by a younger author, depicting the situation in the Yugoslav People's Army in a peculiar and satirical manner". The circle of the magazine's associates was evaluated as "a group of young, ideologically rather confused provincial intellectuals, who have been able to affirm themselves primarily due to the weakness of the barely ideologically-visible Party and student organisation at the university, assisted by the notable behind-the-scenes influence of ideologically-incompatible anti-Marxist professors". Even though the magazine's associates officially referred to Marxism, the Party analysts evaluated them as an ideologically heterogeneous group, not dominated by intellectuals supportive of the authorities: "The group is very diverse, as it does not possess any clear and single ideological orientations; and it is constantly bickering over numerous issues. Some members of the League of Communists do indeed support it, but so do certain religious elements." ${ }^{1}$

\footnotetext{
$38 \quad$ AS 249, t.e. 183 , doc. $4 / 6-57$.

39 Janko Kos, "Nekrolog za besedo", p. 47.

40 "S seje sveta za kulturo in umetnost", Slovenski poročevalec, 18 (7. 4. 1957), no. 81: 2; A DSP, Korespondenca 1957-I, Dopis uredništva Besede.

41 AS 1589, III, t.e. 76, Informacija, May 20, 1957.
} 
The associates of the abolished Beseda magazine started negotiating with the leadership of the Prešernova družba company about the possible use of the subsidy for the publication of a new magazine. Boris Ziherl reported to the central Slovenian Party leadership that one of the conditions of the Prešernova družba company was that such an editorship be appointed "that can guarantee that similar issues will no longer occur; which is why the former editors can no longer be members of the new editorship. ${ }^{42}$ The negotiations between Veno Taufer, editor of the literary supplement to the Tribuna student magazine, and Janez Vrhunc, President of the University Committee of the Student Association of Yugoslavia in Ljubljana, were more successful. Vrhunc also headed the University Committee of the League of Communists and ensured the "consent" for the publication of a new young generation's magazine from Boris $\mathrm{Zi}$ herl as well. ${ }^{43}$ As of February 1956, Ziherl was the leader of the newly-established ideological commission of the League of Communists of Slovenia, which represented another attempt at strengthening the Party influence in the cultural field, although without such powers as the Agitprop had enjoyed a few years earlier.

After the negotiations were completed, Beseda got a successor, named after the year of its establishment: Revija 57. The role of the formal founder and publisher of the new magazine was assumed, as provided for by law, by the University Committee of the Student Association of Yugoslavia in Ljubljana. The Slovenian political leadership believed that thus a body that could successfully monitor the activities of the magazine finally existed. However, Janez Vrhunc was well aware of the difficulties, as the Student Association did not possess any considerable influence on the ranks of the students. Veno Taufer and Vital Klabus were appointed as the editors of the Revija 57 magazine, while the last editors of Beseda - Janko Kos and Ciril Zlobec - were forbidden from becoming members of the editorship. The abolishment of Beseda was the first major judicial intervention in the cultural activities after World War II; and the cultural circles - even Party members - expressed their unanimous rejection of such a move by the authorities. ${ }^{44}$

The abolished magazine was soon replaced by a new publication with a similar concept, print, equipment, and circle of associates; which is why the Party leadership often simply referred to it as Nova Beseda ("The New Beseda"). The only positive outcome of this scandal was the fact that the former magazine without a publisher was replaced by a magazine with a publisher, whom the authorities could approach in order to influence the editorial policy.

\footnotetext{
$\overline{42}$ AS 1589, IK, t.e. 7, Zapisnik seje izvršnega komiteja CK ZKS, May 14, 1957, p. 7.

43 Mateja Režek, “Ideološko ozadje ukinitve Revije 57”, Nova revija, 13 (1994), no. 151-152: 194.

44 AS 1589, IK, t.e. 7, Zapisnik seje izvršnega komiteja CK ZKS, May 14, 1957, pp. 7-8; AS, 1589, III, t.e. 76, Informacija, May 20, 1959.
} 


\section{The Revija 57 magazine}

As the authorities knew what to expect from the "Nova Beseda" magazine, they followed its every step since the establishment. In his personal materials, the editor of the magazine Vital Klabus discovered records of his two meetings with Boris Ziherl already before the magazine's establishment in May 1957: he attended the first one by himself as the future editor; while he was already accompanied to the second one by the new editorship. ${ }^{45}$ The highest leadership of the League of Communists of Slovenia discussed the very first issue of the new magazine, published on 20 September 1957. Their remarks were not severe, as they believed that "no administrative measures against the new magazine have to be implemented. However, the collaboration with the communists who lead or take part in the magazine should be encouraged, in order to ensure that the individual questions can be solved by means of a political struggle among the magazine's associates themselves". ${ }^{46}$

The leading communists believed it would be better if other young intellectuals engaged in debates with the associates of the Revija 57 magazine - so that the struggle would not take place at the level of the older (politically influential) intellectuals against the young generation. This in fact happened at the congress of the People's Youth of Slovenia on 13 and 14 September 1957 in Celje. Writer Vladimir Kavčič, otherwise himself a member of the editorship of the competitive magazine Mlada pota, gave a negative assessment of the abolished Beseda magazine, even though a part of the young generation at the university saw it as "the gazette of the resistance against the existing social order". His evaluation of the first issue of the abolished magazine's successor Revija 57 was just as negative: he mentioned the contributions that he did not agree with and stated "that the student organisation was wrong when it brought these people together and let them have a magazine". Unlike the leading ideologues, Kavčič, however, believed that the standpoints should be clarified by means of a permanent ideological confrontation, "without silencing anyone, as it is sometimes implied". ${ }^{47}$

The political leadership pressured the Student Association into appointing several members of the University Committee of the League of Communists for the editorship of the Revija 57 magazine. However, the youth political organisations chose not to respond to these appeals. In the meantime, certain contributions, published in volume 3-4 of Revija 5, indicated that the new magazine was even more critical of the authorities as its predecessor. While the Beseda magazine still expressed its ideas subtly, so that one had to read between

\footnotetext{
45 Vital Klabus, “Pričevanje o Reviji 57 in Perspektivah”, Borec, 48 (1996), no. 551/552: 111, 117 119.

46 AS 1589, IK, t.e. 7, Zapisnik seje izvršnega komiteja CK ZKS, September 20, 1957, p. 11.

47 AS 1799, t.e. 78, VI. kongres LMS, September 13-14, 1957, Celje, discussion: Vlado Kavčič; Režek, "Ideološko ozadje ukinitve Revije 57", p. 195.
} 
the lines, Revija 57 published articles, especially those written by Jože Pučnik, that were directly and severely critical of the situation in the society as well as understandable even to the less demanding readers.

At the session of the Ideological Commission on 26 November 1957, the leadership of the League of Communists of Slovenia held the first serious discussion about the problems caused by the Revija 57 magazine. In his paper on the ideological influences among the young intelligentsia, the member of the Central Committee of the People's Youth of Slovenia Vinko Trček claimed that the magazine was mostly responsible for the (in the opinion of the authorities) ideologically poor state of the young generation: 'In certain ways, 'Revija 1957' is characteristic of the shortcomings of the loyal forces at the university. Lately certain people that we count among the remainders of the leading bourgeois ideological circles and even the Catholic intelligentsia have detected certain possibilities for their engagement here. We have had some examples of these people inviting the individual editors and associates of 'Revija 1957' to their homes. Some of them have allegedly responded to these invitations. Communists are also often attacked, in a particular manner, in the discussions of the literary club (at the department of Slavic studies)." ${ }^{8}$ Trček's paper and the consequent discussion attested to a new step that the authorities took in their evaluations of the political danger, supposedly represented by the circle of the younger generation of intellectuals. While in case of Beseda the ideologues only attacked the magazine's ideas, Revija 57 was already reproached with the formation of informal groups that could potentially create a strong political opposition.

The associates of the Revija 57 magazine were characterised as the part of the young generation that had not yet comprehended the momentous changes in the society after 1945, and which was far too uncritical in its estimates of the Western society's level of development. With such a standpoint, Revija 57 had, in the opinion of the Party leadership, started to exert too much of an influence on the students of the Faculty of Arts. The ideologues were especially concerned about the power of the Revija 57 circle at the department of humanities, as this impeded the League of Communists of Slovenia in its envisioned transformation of the University according to its own taste and thus the possibility of the (ideological-political) influence over the future generations of intellectuals. In accordance with such estimates, Ziherl proposed the following: "We will not achieve anything with administrative measures - we might even cause these people to consolidate their ranks even further. We can only succeed if we activate everything that is healthy among the youth - if we show how rotten all of this is, that it does not mean anything, actually. It is very important that the youth contribute to this themselves, from within their own organisations." ${ }^{49}$

48 $\quad$ AS 1589, III, š. 76, Zapisnik seje ideološke komisije CK ZKS, November 26,1957, pp. 9-10.

49 Ibidem, pp. 28-31. 
The authorities were able to exert a stronger political pressure against Revija 57 than on Beseda because a formal publisher now in fact existed, in accordance with the provisions of the Publishing Act. However, the Student Association of Yugoslavia in Ljubljana did not take advantage of this, as in the opinion of the authorities Janez Vrhunc, the representative of the publisher, failed to perform his role, as he refrained from blocking the publication of any articles. Thus contributions would now be published that aimed their criticism at all of the social and state system rather than at the ideological monopoly of the Party (which had been what the Beseda magazine had still limited itself to). During the preparations for the 7th Congress of the League of Communists of Yugoslavia, which took place in April 1958 in Ljubljana, the authorities once again strengthened their pressure against their ideological opponents. In February 1958 the University Committee of the League of Communists removed Janez Vrhunc from his position because he performed his role of a censor poorly, and in March 1958 Rado Jan, the secretary of the League of Communists organisation at the Faculty of Arts, was appointed instead of Vrhunc. ${ }^{50}$

In July 1958 the editorship of Revija 57 was informed that the Secretariat for Culture and Education of Slovenia had proposed that the magazine's subsidy be terminated, which is why in the following months they called upon the competent state authority several times - at face-to-face meetings or in writing - not to go through with this. ${ }^{51}$ However, the appeals were unsuccessful, and the official proposal, presented by the Publishing Promotion Fund of the Council for Culture and Education of the People's Republic of Slovenia, included Revija 57 among the magazines whose subsidies would allegedly be revoked. After a heated discussion, the Council for Culture and Education of Slovenia rejected this proposal. However, the Council did support the proposal of the Council President Boris Kocijančič: that the magazine should be subsidised until the end of the year, after which "the criteria taken into account by the commission that proposed the termination should be considered thoroughly by the magazine itself as well as by the Student Association". Therefore Revija 57 "cannot count on receiving the subsidy in the coming year any longer, should the ideas that the magazine discusses be overly incompatible with our cultural policy". ${ }^{2}$ The editorship of Revija 57 was therefore warned not to publish any politically undesirable contributions any longer, lest the magazine, should it not desist, lose its subsidy with the end of 1958. In the political reality at the time, to lose the subsidy was synonymous with abolishment.

The issue was also discussed by the forums that were supposed to oversee the activities of the Revija 57 magazine. The Central Committee of the Peo-

\footnotetext{
Režek, “Ideološko ozadje ukinitve Revije 57”, p. 196.

Klabus, "Pričevanje o Reviji 57 in Perspektivah”, pp. 113-114.

52 Režek, “Ideološko ozadje ukinitve Revije 57”, pp. 198-199.
} 
ple's Youth of Slovenia and the university committee of the League of Students gathered at a joint session on 4 October 1958. In their opinion, Revija 57 failed to focus on the truly relevant contemporary issues. In the introductory paper, Blaž Vrečko was very critical in his admission that the magazine's influence, "which everyone sees as a 'delicate matter' now", was strong because nobody could keep up with it: "And yet this magazine deals with crucial problems, even though differences of opinion never arise within it - which is characteristic of all other publications. However, whenever we focus on this issue, we do it in a very primitive way, as if we were forgetting that we are dealing with extremely clever people." When Vrečko stated the simple fact "that Revija 57, a gazette of the Student Association, is surpassing the University by focusing on topical issues" ${ }^{53}$, he willingly or unwillingly underlined what the authorities were most worried about.

In October 1958, only a month after the first proposal that Revija 57 be abolished, the authorities initiated an action that led to the magazine's ultimate demise. The severe criticism of the society in the issue 5-6 of the magazine's second volume was selected as the formal reason for this measure, even though similar critiques had also been published in the earlier issues. In the aforementioned issue, however, the very editorial was very critical of the session of the Council for Culture and Education of the People's Republic of Slovenia and the proposal that the subsidy for Revija 57 be abolished. Furthermore, two articles, published in the back of the magazine, focused on the anniversary of the abolishment of the Prešeren's Theatre in Kranj and its negative consequences, as well as criticised the publishing houses that refused to publish the collection of poetry by Dane Zajc due to the poet's "ideological standpoints". ${ }^{4}$

An article by Jože Pučnik, entitled Naša družbena stvarnost in naše iluzije (Our Social Reality and Our Illusions), had been prepared for this issue as well, and Boris Ziherl assessed it as "Đilasist". Already before it was printed, a "representative of the Student Association in this editorship" submitted the text for review and "inquired what to do with this article". Ziherl told him: "You are a representative of the Student Association in this editorship, and if you vetoed the editors, then you have the right to appeal to those who have appointed you for this editorship - meaning the Student Association - and have them reach a decision on this matter." Ziherl reported to the leading politicians that "this in fact happened, and the committee of the Student Association refused the publication of the article in question". However, because the editorship threatened to publish an empty page instead of the censored article, "the representative of the Student Association once again came to me for advice". ${ }^{5}$

\footnotetext{
AS 1799, t.e. 83, Zapisnik seje predsedstva CK LMS in uni. odbora ZŠJ, October 4, 1958, p. 7.

4 AS 1589, IK, t.e. 12, Revija 57.

55 AS 537, t.e. 27, Seja predsedstva SZDLS, November 6, 1958, pp. 47-48.
} 
The action against the Revija 57 magazine was initiated in October 1958 by the Internal Affairs Administration, which proposed that the issue 5-6 be confiscated. On 31 October 1958, the issue, ready for printing, was confiscated at the printing house in Kočevje. On the same day the Internal Affairs Administration arrested Jože Pučnik, interrogated the editor and a few associates of the magazine, threatened them with judicial proceedings, and confiscated the archive of the Revija 57 magazine from the editor Vital Klabus. The editors Veno Taufer and Vital Klabus complained to the Internal Affairs Administration and the regional committee of the Socialist Alliance of Working People in Ljubljana. This, however, did not influence the decision of the highest authorities. ${ }^{56}$

Due to his complaint, the editors were received by Janez Vipotnik, the Secretary of the District Committee of the League of Communists of Slovenia in Ljubljana, who was surprised at the standpoint that they "argued for regarding the matters that are completely clear in our society". According to Vipotnik, Taufer and Klabus argued for the right of every individual to express his or her opinion, claiming that there should not be any reservations with regard to the publication of different standpoints: "I found these matters very peculiar and I tried to make them understand that every state has certain restrictions in place that have to be observed, and if someone fails to observe them, then they should also expect that suitable measures will be taken against them - even administrative measures, should everything else fail." Taufer and Klabus resolutely rejected Vipotnik's hint that they should remove the disputable articles from the magazine. Naturally, this meant that on 5 November 1958 the District Court of Ljubljana approved the demand of the public prosecutor and confiscated the magazine. ${ }^{57}$

The fate of the magazine and its associates was decided at the session of the Presidency of the Socialist Alliance of Working People of Slovenia on 6 November 1958. Vipotnik reported on the complications regarding the confiscation of the magazine. The discussion addressed the question why such a magazine was subsidised at all, when the working people, who supported education by paying their taxes, did not benefit from it. In Ziherl's opinion, Revija 57 was "Đilasist", which had already become a standard assessment that had also applied to the Beseda magazine. However, this influence was nevertheless not as significant as the leading Party ideologues estimated. ${ }^{58}$ According to Ziherl, "Đilasism" in the field of culture was apparent from the standpoint of the yo-

\footnotetext{
56 A DSP, Korespondenca 1958/II, Dopis uredništva Revije 57, Novemebr 2, 1958; AS 1589, IK, t.e. 12, Zadeva: »Revija 57 «, and Naši nadaljnji ukrepi in rezultati preiskave proti skupini »Reviji 57«; Klabus, “Pričevanje o Reviji 57 in Perspektivah”, pp. 115-116, 127-129.

57 AS 537, t.e. 27, Seja predsedstva SZDLS, November 6, 1958, pp. 40-42.

58 More see in: Božo Repe, "Vpliv »đilasovščine« na Revijo 57 in Perspektive”, Borec, 46 (1994), no. 535/537: 928-940.
} 
unger generation that cultural works should not be assessed from the political viewpoint, and certainly not with ideological criteria, defined in advance. Josip Vidmar was against strict sanctions, while the suggestions and questions of the other members of the Presidency of the Socialist Alliance of Working People of Slovenia indicated that the Revija 57 circle would eventually be retaliated against: how could authors of such articles be assistants at the University; why was such a magazine subsidised; this was an organised action in order to incite revolt among the dissatisfied; it was not true that not enough magazines were published, as the youth also had the Mlada pota magazine. ${ }^{59}$

The Internal Affairs Administration kept informing the political leadership about its activities. In the middle of November 1958 it reported on the illegal organisation that Jože Pučnik was supposedly forming. After the interrogations of the magazine's associates it was established that the majority of the editorship agreed to publish the contributions that the police identified as "hostile propaganda"; that they were organising the formation of a publishing house called Založba 1551, which would publish texts by authors like Sartre; and that they planned to expand the editorship with "negative elements" like Lojze Kovačič and Janko Kos. According to the report of the Internal Affairs Administration, the young intellectuals believed that "the measures are an arbitrary and offhanded way of causing alarm among them, but they should not fall for it". The fact that the magazine was also defended by certain renowned cultural workers of the older generation was seen as problematic. The Internal Affairs Administration mentioned Josip Vidmar as the first among these, and Vladimir Kralj allegedly stated that the whole affair had been instigated by the "anti-cultural Carniolans, who will be forced to desist at the demand of Belgrade", while the youth was also praised by the ranks of the Catholic intelligentsia, from Anton Vodnik to Edvard Kocbek. ${ }^{60}$

On 5 December 1958, at its IX plenum, the League of Communists of Slovenia indicated publicly that the authorities would intensify their attitude towards the young intellectuals (as it is apparent from the reports of the Internal Affairs Administration, intended for the Party leadership exclusively). Boris Ziherl addressed the subject of ideological-political problems and mentioned Revija 57 as one of the major issues. Janez Vipotnik discussed it in more detail as well. He mentioned that the associates of the Revija 57 magazine "want to explore the social issues from the position of intellectuals not oriented in terms of class", that the magazine involved too many "assistants" and not enough "students", and that the circle of this magazine "undoubtedly harbours a negative attitude towards our social reality". ${ }^{61}$

$59 \quad$ AS 537, t.e. 27, Seja predsedstva SZDLS, November 6, 1958, pp. 40-56.

60 AS 1589, IK, t.e. 12, Naši nadaljnji ukrepi in rezultati preiskave proti skupini »Revije 57 «.

${ }_{61}$ AS 1589, IK t.e. 7, Stenografski zapisnik IX. plenarne seje CK ZKS, December 5, 1958, pp. 1-13 in 32-38. 
In December as well as in the subsequent months, Revija 57 was frequently subject to criticism by the leading politicians and a topic at numerous sessions of the highest authorities. Boris Ziherl and Janez Vipotnik were among the most zealous ideological critics, while Mitja Ribičič would inform the leading structures on the investigations carried out by the Internal Affairs Administration. The politicians kept reiterating that this was a group of younger intellectuals who were establishing an illegal hostile organisation, disseminated anti-state propaganda and Đilasism, called the workers to strikes, etc. The proceedings were accompanied by severe media frenzy, while the opposing side had no chance to defend itself. The interrogations dragged on, and finally the editors Klabus and Taufer as well as Taras Kermauner were sentenced to ten days in prison. The retaliation and intimidation culminated in the trial against the author of the most disparaging contributions about the contemporaneous political situation, Jože Pučnik, who was sentenced to nine years in prison on 30 March 1959. Furthermore, all those who congratulated Pučnik on his unwavering composure after the proceedings were excluded from the League of Communists. ${ }^{62}$ The punishment would also have an impact in the years to come, as Veljko Rus and Taras Kermauner soon lost their position as assistants at the Faculty of Arts of the University in Ljubljana.

\section{Conclusion}

In the one-party and ideologically monolithic systems, editorships cannot publish magazines according to their aspirations and wishes. Apart from their opinion it is also the opinion of the monopoly authority or its ideologues that counts. The censors' opinion of the magazines is apparent from public critiques, amount of the subsidy, prevention of the publication of individual contributions or whole issues, as well as the more serious political pressures like interrogations, threats, and judicial proceedings. The magazines of the young generation in Slovenia in the first decade after World War II were no exception to this rule. They enable us to follow the level of democracy in the society, the abandonment of the most one-sided ideological standpoints in the Slovenian Party leadership, as well as the growth of the critical intelligentsia's political power. On the one hand, changes in the activities of the Communist Party or the League of Communists are apparent, while on the other hand the increasingly resolute criticism and aggressiveness of the intellectuals is evident as well.

During well over a decade, the magazines of young intellectuals meant a significant shift in the search for one's own critical attitude towards the social si-

\footnotetext{
62 AS 1589, III, š. 68, Informacije, no. 49, March 11, 1959, p. 6; no. 57, April 9, 1959, p. 10; no. 59, April 18, 1959, p. 4; Janko Lorenci, Jože Pučnik (Ljubljana: Emonica, 1960), pp. 68-74; Klabus, "Pričevanje o Reviji 57 in Perspektivah", pp. 116-117.
} 
tuation. The first volumes of the Mladinska revija magazine still attested to the uncritical adoption of the mentors' ideas, while the last volumes were already completely different. It is true that Mladinska revija focused predominantly on literature, but even the very publication of works that completely rejected the declared socialist realism indicated that the young generation did not intend to obey and carry out ideas that were formed elsewhere. The shift from Mladinska revija to the Beseda magazine bid the mentorship farewell. The editorship of Beseda strengthened essayistics in particular, though its critical attitude was still restricted to the developments in the cultural sphere. However, this changed with the establishment of the Revija 57 magazine, which extended its topics to the issues of the society in general.

As the critical attitude of the young intelligentsia developed, the political pressures against their magazines mounted as well. The earliest and lightest form of pressure was the threat that the magazines' subsidies could be terminated. The first editorship to face this threat was that of the Beseda magazine towards the end of 1952, although it was unclear where the proposal came from. When Beseda and Revija 57 were abolished, however, the authorities made it clear that the subsidies had been abolished due to the "ideological inappropriateness" of these magazines' contents. The severity of the retaliation indicates that the authorities believed the young intellectuals were increasingly influential in public. The Mladinska revija magazine was simply a target of political criticism. In case of the Beseda magazine, the measures included the termination of the subsidy and the confiscation of its last issue with a court order. However, the retaliation against Revija 57 also involved judicial proceedings and severe prison sentences.

The authorities were increasingly merciless in their dealings with the young intellectual generation, because they saw the young intelligentsia as an increasing political danger. Until then, in the post-war period, the State Secretariat for Internal Affairs (or the Ministry of the Interior) had paid more attention to the politicians of the pre-war political parties and their potential subversive acts. However, in its 1958 annual report the Ministry of the Interior clearly stated for the first time that the older generation no longer represented a danger, and that this role had been assumed by the new generation: "In view of the hostile propaganda activities of the remainders of the bourgeois parties, we should emphasise that these have mostly been limited to a variety of discussions and commentaries - i.e. that no organised forms of hostile activities have been noted. However, it is the younger intelligentsia that is problematic, as it does not agree with the socialist order in our country." The police analysts added that this was especially true of the Revija 57 circle. ${ }^{63}$ In the special report on this magazine, drawn up for the Slovenian Party leadership, the State Security Administration added an evaluation that mentioned the younger intellectual generation as the potential opposition for the first time: "Within the 
circle of their supporters, they endeavour to create an appearance that they are being persecuted as the opposition - but a constructive and progressive opposition, which is therefore subject to persecution by the authorities. By persecuting them, however, the authorities have demonstrated that they are no longer progressive." 64

\section{Der Blick kommunistischer Ideologen auf die Zeitschriften der jüngeren Generation}

\section{Zusammenfassung}

In diesem Beitrag wird die zunehmende Kritik analysiert, mit der die jüngere Generation slowenischer Intellektueller aktuelle gesellschaftliche Themen von den ersten Nachkriegsjahren bis zum Ende der 1950er Jahre behandelte. Diese kritische Einstellung entwickelte sich allmählich ab Anfang der 1950er, auch weil die erste Literaturzeitschrift der Nachkriegszeit Mladinska revija, die von 1946 bis 1951 erschien, weiterhin unter strenger behördlicher Aufsicht stand. In der von 1951 bis 1957 herausgegebenen Nachfolgezeitschrift Beseda wurden bereits radikalere Abhandlungen und Gesellschaftskritiken veröffentlicht. Ein ähnlicher Kreis von Mitarbeitern der darauffolgenden Zeitschrift Revija 57 (die von 1957 bis 1958 veröffentlicht wurde) hatte eine noch kritischere Haltung gegenüber der Situation im Staat, was die Behörden so nicht erwartet hatten. Der Beitrag beleuchtet zwei parallel verlaufende Prozesse: einerseits eine immer kritischere Einstellung der Intellektuellen der jüngeren Generation zu den Behörden und andererseits der wachsende Druck der Behörden auf die Zeitschriften, in denen kritische Texte veröffentlicht wurden. Diese Publikationen waren zu Beginn nur ein Sammelbecken für politisch kritische Stimmen, später wurden ihnen alle Subventionen gestrichen, was letztlich auch zur Einstellung dieser Zeitschriften führte. Ende der 1950er Jahre gab es schon Gerichtsverfahren gegen die Autoren der gesellschaftlich kritischen Artikel. Am Ende des betrachteten Zeitraums sahen führende Politiker die jüngere Generation der Intellektuellen als (Kultur) Opposition.

63 AS 1931, A-13-O, Letno poročilo za leto 1958, pp. 3-4.

${ }_{64}$ AS 1589, IK, t.e. 12, Naši nadaljnji ukrepi in rezultati preiskave proti skupini “Revije 57”, p. 4. 


\section{Bibliography}

\section{Archives:}

A DSP - Arhiv Društva slovenskih pisateljev

AS - Arhiv Republike Slovenije

AS 249 - Svet za prosveto in kulturo LRS

AS 537 - Republiška konferenca Socialistične zveze delovnega ljudstva Slovenije

AS 1589 - Centralni komite Zveze komunistov Slovenije

AS 1799 - Centralni komite Ljudske mladine Slovenije

AS 1931 - Republiški sekretariat za notranje zadeve Socialistične republike Slovenije

\section{Literature:}

Beseda, 1 (1951-52), no. 1: 1-2.

"Glavne misli iz diskusije po referatih". Mladinska revija, 5 (1949-50), no. 9-10: 442-452.

Bratko, Ivan. "O kulturi in umetnosti naše mlade generacije”, Mladinska revija, 4 (1948-49), no. 3-4: 65-73.

Dimić, Ljubodrag. Agitprop kultura: agitpropovska faza kulturne politike u Srbiji : 1945-1952. Beograd: Rad, 1988.

Gabrič, Aleš. “Od Mladinske revije do Perspektiv”. Borec, 46 (1994), no. 535/537: 1068-1086.

Gabrič, Aleš. "Preokret kulturno-političke linije KPJ posle Rezolucije Informbiroa”. Istorija 20. veka, 18 (2000), no. 1: 101-108.

Gabrič, Aleš. "Zveza mladih kulturnih delavcev Slovenije”, Nova revija, 10 (1991), no. 113-114: 1235-1245.

Gabrič, Aleš. Slovenska agitpropovska kulturna politika : 1945-1952. Ljubljana: Mladika, 1991.

Klabus, Vital. "Pričevanje o Reviji 57 in Perspektivah". Borec, 48 (1996), no. 551/552: 111-136.

Kos, Janko. “Nekrolog za Besedo”. Perspektive, 2 (1961/62), no. 11: 36-47.

Kos, Janko. Ideologi in oporečniki : spominjanja. Ljubljana: Znanstvena založba Filozofske fakultete, Beletrina, 2015.

Kosmač, France. “Naš obračun”, Mladinska revija, 2 (1947), no. 1: 1-4.

Kozak, Juš. "Nekaj zapiskov ob zaključku leta”. Novi svet, 1 (1946), no. 10: 819-820. 
Lasić, Stanko. Krležologija ili povijest kritičke misli o Miroslavu Krleži - knjiga četvrta. Stvaranje kulta: 1945-1963. Zagreb: Globus, 1993.

Ljudska pravica, 13 (26. 1. 1952), no. 4: 10.

Lorenci, Janko, Jože Pučnik. Ljubljana: Emonica, 1990.

Peković, Ratko. Ni rat ni mir : panorama književnih polemika 1945-1965. Beograd: Filip Višnjić, 1986.

Repe, Božo. "Vpliv 'đilasovščine’ na Revijo 57 in Perspektive”. Borec, 46 (1994), no. 535/537: 928-940.

Režek, Mateja. “Ideološko ozadje ukinitve Revije 57”. Nova revija, 13 (1994), no. 151-152: 194-206.

"S seje sveta za kulturo in umetnost". Slovenski poročevalec 18 (7. April 1957), no. 81: 2 .

“Urednikovi zapiski”. Beseda 2 (1953), no. 2: 123.

"Uredništvo". Mladinska revija 1 (1946), no. 1: 1-2.

"Uredništvo". Beseda, 2 (1953), no. 1: 1.

Zapisniki politbiroja CK KPS/ZKS 1945-1954 (Ljubljana: Arhivsko društvo Slovenije, 2000). 